\title{
Wolbachia introduction into Lutzomyia longipalpis (Diptera: Psychodidae) cell lines and its effects on immune-related gene expression and interaction with Leishmania infantum
}

Daniela da Silva Gonçalves ${ }^{1}$, Iñaki Iturbe-Ormaetxe ${ }^{2}$, Andrea Martins-da-Silva $^{3}$, Erich Loza Telleria ${ }^{3}$, Marcele Neves Rocha' ${ }^{1}$, Yara M. Traub-Csekö ${ }^{3}$, Scott L. O'Neill ${ }^{2}$, Maurício Roberto Viana Sant'Anna ${ }^{4}$ and Luciano Andrade Moreira ${ }^{1 *}$ (I)

\begin{abstract}
Background: The leishmaniases are important neglected diseases caused by Leishmania spp. which are transmitted by sand flies, Lutzomyia longipalpis being the main vector of visceral leishmaniasis in the Americas. The methodologies for leishmaniasis control are not efficient, causing 1.5 million reported cases annually worldwide, therefore showing the need for development of novel strategies and interventions to control transmission of the disease. The bacterium Wolbachia pipientis is being used to control viruses transmitted by mosquitoes, such as dengue and Zika, and its introduction in disease vectors has been effective against parasites such as Plasmodium. Here we show the first successful establishment of Wolbachia into two different embryonic cell lines from $L$. longipalpis, LL-5 and Lulo, and analysed its effects on the sand fly innate immune system, followed by in vitro Leishmania infantum interaction.

Results: Our results show that LL-5 cells respond to $w$ Mel and $w$ MelPop-CLA strains within the first $72 \mathrm{~h}$ postinfection, through the expression of antimicrobial peptides and inducible nitric oxide synthase resulting in a decrease of Wolbachia detection in the early stages of infection. In subsequent passages, the wMel strain was not able to infect any of the sand fly cell lines while the wMeIPop-CLA strain was able to stably infect Lulo cells and LL-5 at lower levels. In Wolbachia stably infected cells, the expression of immune-related genes involved with downregulation of the IMD, Toll and Jak-Stat innate immune pathways was significantly decreased, in comparison with the uninfected control, suggesting immune activation upon Wolbachia transinfection. Furthermore, Wolbachia transinfection did not promote a negative effect on parasite load in those cells.

Conclusions: Initial strong immune responses of LL5 cells might explain the inefficiency of stable infections in these cells while we found that Lulo cells are more permissive to infection with Wolbachia causing an effect on the cell immune system, but not against in vitro L. infantum interaction. This establishes Lulo cells as a good system for the adaptation of Wolbachia in L. longipalpis.
\end{abstract}

Keywords: Wolbachia, Lutzomyia longipalpis, Lulo cell, LL-5 cell, Leishmania infantum

\footnotetext{
* Correspondence: luciano@minas.fiocruz.br

${ }^{1}$ Grupo Mosquitos Vetores: Endossimbiontes e Interação Patógeno Vetor,

Centro de Pesquisas René Rachou - Fundação Oswaldo Cruz, Av. Augusto de

Lima 1715, 30190-002. Belo Horizonte, Belo Horizonte, MG, Brazil

Full list of author information is available at the end of the article
}

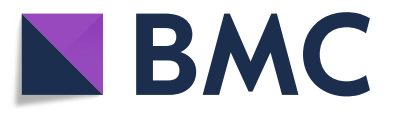

(c) The Author(s). 2019 Open Access This article is distributed under the terms of the Creative Commons Attribution 4.0 International License (http://creativecommons.org/licenses/by/4.0/), which permits unrestricted use, distribution, and

reproduction in any medium, provided you give appropriate credit to the original author(s) and the source, provide a link to the Creative Commons license, and indicate if changes were made. The Creative Commons Public Domain Dedication waiver (http://creativecommons.org/publicdomain/zero/1.0/) applies to the data made available in this article, unless otherwise stated. 


\section{Background}

Leishmaniasis is a spectrum of important epidemiological diseases, endemic in 98 countries with over 1.5 million cases reported annually worldwide. About one billion people live in areas of high transmission risk [1, 2]. Visceral leishmaniasis (VL) is caused by Leishmania donovani in the Old World and L. infantum in parts of the Old World and New World [3], reaching up to 400,000 cases and around 40,000 deaths every year [2, 4, 5]. Currently, there is no vaccine for humans, so prevention and control of leishmaniasis are based on early diagnosis, effective drug administration [6] and protecting humans against the insect bite by using, for example, bednets, repellents and insecticide treatment $[2,7,8]$.

Recently, the endosymbiont bacterium Wolbachia has been used as an alternative strategy to control vectorborne diseases, through the reduction or blocking of pathogen infections. This bacterium naturally infects around 40 to $70 \%$ of arthropods and some nematodes, being maternally transmitted through the eggs to subsequent generations [9-11]. The broad natural prevalence of Wolbachia in invertebrates has prompted studies on its potential to protect the host against pathogens. Previous studies have shown that the presence of Wolbachia can protect Drosophila against RNA viruses [12, 13] and its presence can induce the upregulation of immune genes, such as Relish and Dorsal, and also antimicrobial peptides (AMPs), i.e. attacin and diptericin [14]. Later, different strains of this bacterium were introduced into mosquitoes, upregulating immune related genes, such as TEP1, Myd88, SOCS36E, Cactus and the AMPs Defensin and Cepropin. This led to the reduction of infection by pathogens that cause different diseases such as dengue, chikungunya, malaria and Zika [15-22].

Wolbachia has been detected in sand flies of the genera Phlebotomus and Lutzomyia, but the impact of Wolbachia on the Leishmania infection load has not been reported. Phlebotomus papatasi and Phlebotomus perniciosus are naturally infected with strains $w$ Pap and $w$ Prn, respectively, whereas both Lutzomyia shanonni and Lutzomyia whitmani are infected with the strain $w$ Whi $[11,23,24]$. Lutzomyia longipalpis, the main vector of L. infantum in the Americas [25, 26], was not found to be naturally infected with Wolbachia in some studies [11, 23, 26]. However, more recently, Wolbachia was detected with a low infection rate in L. longipalpis in a small population in Brazil, which suggests either a rare event of horizontal transmission by the feeding habits of larvae, with the possible acquisition of Wolbachia from decomposing bodies of arthropods, or a localised infection, considering that L. longipalpis is a species complex [27].

In order to successfully transinfect Wolbachia into a new host, previous studies have suggested culturing
Wolbachia from the original host in cell lines belonging to the target species, in order to facilitate the bacteria adaptation to this new organism [21, 28]. After numerous unsuccessful attempts, the Wolbachia strain wMelPop-CLA from Drosophila melanogaster was introduced into Aedes aegypti mosquito embryos through microinjections, following its adaptation to Aedes cell lines for several months. Wolbachia was able to be established and spread into numerous tissues of the adult mosquitoes, to be vertically transmited to their offspring and to transfer some of its Drosophila phenotypes (reduction in longevity and cytoplasmic incompatibility) into the mosquito host [29, 30]. Furthermore, the same Wolbachia strain caused the upregulation of a range of immune-related genes, such as TEPs, prophenoloxidase and AMPs, whereas some genes from the Toll and IMD pathways were downregulated [31, 32].

Most of the studies involving Wolbachia are focused on transinfection into mosquitoes and the effects of the infection on the new host. Considering the importance of leishmaniasis on human health, it is crucial to investigate novel control strategies, mainly because sand fly control through insecticides may be hindered by insecticide resistance [33]. Other potential drawbacks for successful insect control include vector urbanisation [34] and difficulties finding immature stages in nature [35]. Here we tested the possibility of Wolbachia infection into L. longipalpis sand fly cell lines as a first step towards using this bacterium to control leishmaniasis.

In our experiments, we used two embryonic L. longipalpis cell lines: the LL-5 cell line, which consists of at least two cell types, epithelioid and fibroblastoid [36], and the Lulo cells, which are composed of epithelioid cells and previously described as a possible model for Leishmania metabolism and anti-parasitic drug evaluation [37]. Both cells have been reported to be susceptible to Leishmania and used as model for vectorparasite interaction, even though the parasite cycle in the insect is extracellular [36-42].

We performed in vitro infections of Wolbachia using Lulo and LL-5 cell lines, with the aim of obtaining a stable infection. We analysed the expression of immune-related genes upon cell infection. We placed these Wolbachia infected cells in contact with $L$. infantum as a first attempt to verify the response against the parasite, which could lead to the possible use of Wolbachia against Leishmania and a means to control transmission.

\section{Results}

Wolbachia establishment into L. longipalpis cell lines The response of L. longipalpis LL-5 cells against infection with Wolbachia strains wMel and wMelPop-CLA was analysed at early stages of interaction for the first $72 \mathrm{~h}$ 
post-infection with the bacteria. The detection of both $\mathrm{Wol}$ bachia strains decreased gradually from early time-points until $72 \mathrm{~h}$ post-infection (Fig. 1a). The expression of immune related genes was evaluated to understand these cells response to early contact with these strains, from 6 to $72 \mathrm{~h}$ post-interaction. When compared to the non-infected control group, LL-5 cells responded to $w$ Mel increasing the expression of the transcription factors at $12 \mathrm{~h}$ post-infection to Dorsal and at $24 \mathrm{~h}$ to STAT, while for $w$ MelPop, the cells also responded to Dorsal and Relish both at $12 \mathrm{~h}$ post-infection (Fig. 1c, e, g). Cactus, which is the repressor of the Toll pathway, did not present a significant expression variation (Fig. 1b), while the expression of Caspar and PIAS, repressors of the IMD and Jak-Stat pathways, increased at 48 and $12 \mathrm{~h}$ post-infection, respectively (Fig. 1d, $\mathrm{f})$, in response to wMelPop-CLA infection. For $w \mathrm{Mel}$, the AMPs, which are effector molecules of innate immune responses, Attacin at $12 \mathrm{~h}$, Cecropin at $12 \mathrm{~h}$ and $24 \mathrm{~h}$, Defensin 1 at $12 \mathrm{~h}$ and $24 \mathrm{~h}$ and Defensin 2 at $6 \mathrm{~h}$ and $12 \mathrm{~h}$, had significantly increased expression (Fig. 1h-k). Post-wMelPop-CLA infection, the AMPs increased were Attacin at $12 \mathrm{~h}$ and $24 \mathrm{~h}$, Cecropin at $6 \mathrm{~h}, 12 \mathrm{~h}$ and $24 \mathrm{~h}$, Defensin 1 at $6 \mathrm{~h}$ and Defensin 2 at $12 \mathrm{~h}, 24 \mathrm{~h}$ and $48 \mathrm{~h}$. In addition, LL-5 cells expressed high levels of iNOS at $12 \mathrm{~h}$ post-infection with $w \mathrm{Mel}$ and at $24 \mathrm{~h}$ to $w$ MelPop-CLA (Fig. 1l), and low levels of Catalase expression at 48 for $w \mathrm{Mel}$ and $72 \mathrm{~h}$ for $w$ MelPop-CLA post-challenges (Fig. $1 \mathrm{~m}$ ). SOD3A expression was not altered after the two Wolbachia strains challenges (Fig. 1n), except at $6 \mathrm{~h}$ when it was increased post-wMel challenge (see Additional file 1: Table S1 for detailed statistical results).

Later, in order to obtain stable infections of Wolbachia in both L. longipalpis cells (Lulo and LL-5), experiments were performed initially using only the $w \mathrm{Mel}$ strain, due to the lower fitness cost caused by this strain in comparison to the $w$ MelPop-CLA [32]. In parallel, the mosquito cell line RML-12 was infected with the same Wolbachia strain as a control to validate the infection protocol.

Numerous attempts to establish the $w$ Mel strain in $L$. longipalpis cell lines were unsuccessful, mainly due to high cell mortality after Wolbachia infection and slow

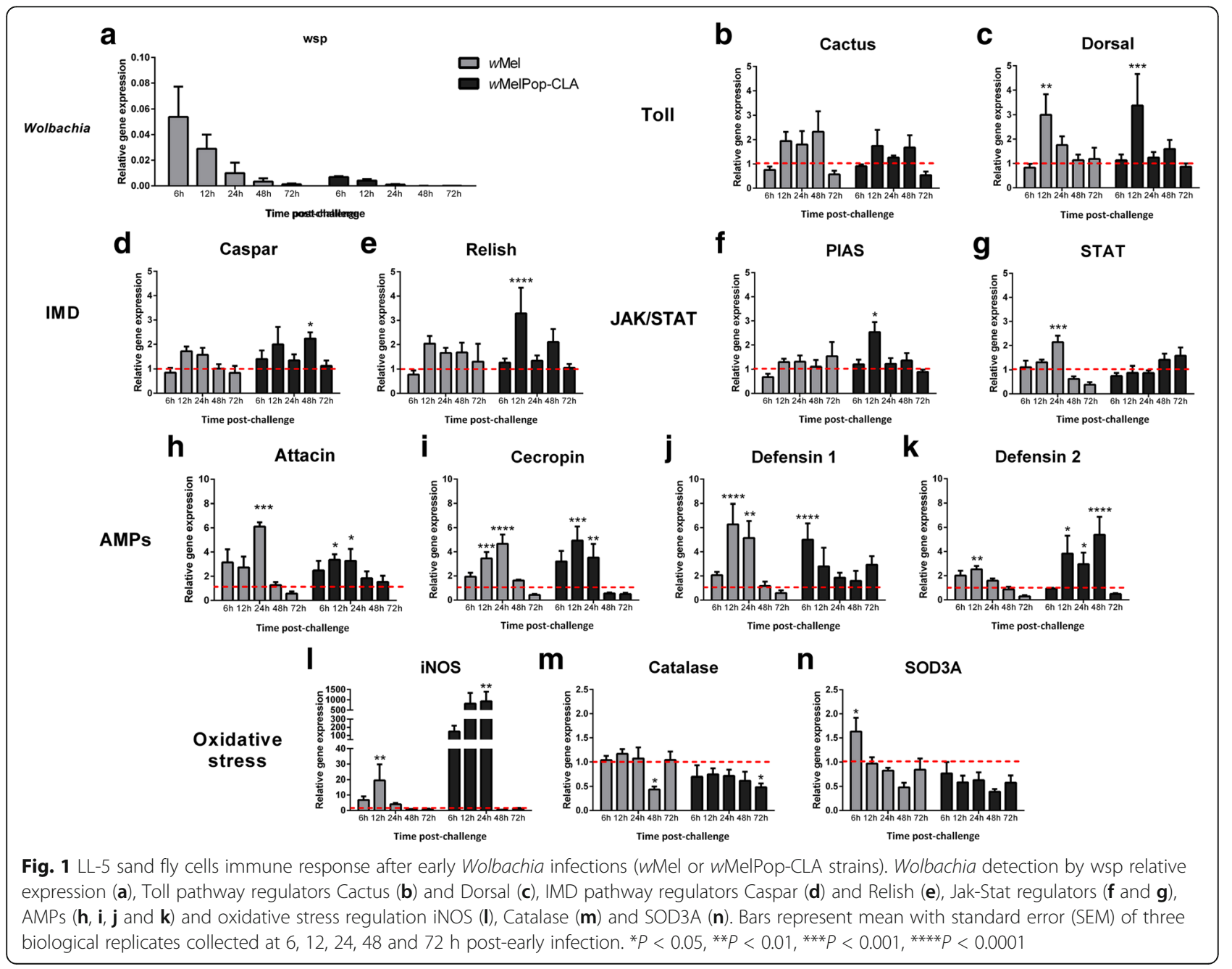


cell growth. After approximately 62 independent attempts in each cell line, we were able to maintain both cells Lulo and LL-5 in culture after the infection process, and the Wolbachia levels were monitored by qPCR in every passage. In subsequent passages, the $w$ Mel density gradually decreased, and was only detectable by qPCR in both cell lines up to the 11th passage after transinfection. Once the levels were below detectable limits, the infected cell lines were discarded. Complementing the qPCR results, analysis using FISH to visualise Wolbachia confirmed the decrease of $w$ Mel over time (Fig. 2d-f).

In contrast, RML-12 cells were able to establish and maintain the $w \mathrm{Mel}$ infection after a single round of infection. We could detect wMel by qPCR and FISH after the initial infection and could further detect the increase of Wolbachia over subsequent cell passages (Fig. 2a-c). These results confirmed the efficiency of the Wolbachia extraction protocol and infection, suggesting that the difficulty lies in the combination of $w \mathrm{Mel}$ and L. longipalpis cells rather than the infection protocol or the quality of the Wolbachia isolation. Furthermore, the L. longipalpis cell lines may be resistant to $w \mathrm{Mel}$ transinfection. Thereafter, we tried transinfections using the wMelPop-CLA strain in both L. longipalpis cell lines. It has been previously shown that $w$ MelPop-CLA has a higher density in cell lines in comparison to $w \mathrm{Mel}$ (unpublished data), which could increase the chances of infection into sand fly cells.

Around 15 attempts to infect each L. longipalpis cell line with $w$ MelPop-CLA were performed. In comparison to LL-5 cells, Lulo cells were more susceptible to infection, and after maintaining Wolbachia in those cells for over 35 passages, we considered $w$ MelPop-CLA successfully established in these sand fly cells. To date, these cells have been maintained for over 70 passages (c.1.5 years) with high levels of infection as monitored by relative qPCR and FISH (Fig. 3a, b). By using FISH, it was possible to confirm that the proportion of Lulo-infected cells was very high, around $80 \%$. Although we could see fluctuations of Wolbachia density by qPCR among the passages, FISH analysis confirmed that the infection rate remained similar.

After establishment in Lulo, we performed $w$ MelPop-CLA infections into LL-5 cells. It was possible to obtain an infection with this strain, as shown in Fig. $3 \mathrm{~d}$, e, but it was more difficult to maintain the infection. In those cells, Wolbachia densities also showed large fluctuations and, in some cases we lost the infection among the passages. However, the average of $w$ MelPop-CLA densities in LL-5 cells were consistently lower in comparison with the same Wolbachia strain infections in Lulo cells.
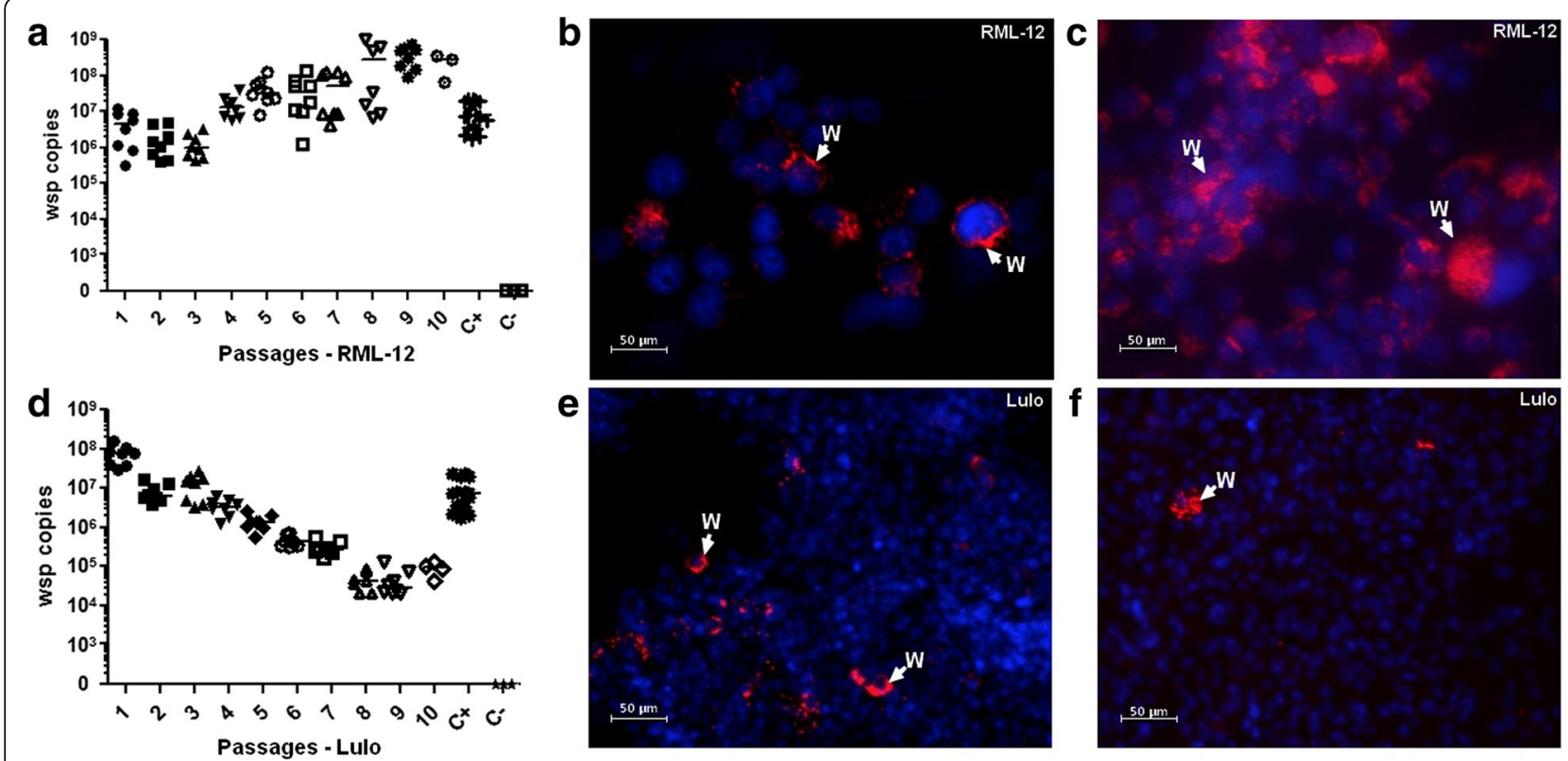

Fig. 2 Wolbachia infection (wMel strain) into mosquito and sand fly cells. Wolbachia introduction into mosquito RML-12 cells showed by absolute quantification (a) and by FISH at the 4th passage (b) and at 7th passage (c) using 40x magnification. In contrast, the decrease of infection into Lulo cells is represented by qPCR (d) and by FISH at the 4th passage (e), and at the 7th (f) in 20x objectives. In a and $\mathbf{d}$, C+ represents the positive control and C- the negative control. The LL-5 cells showed similar results to Lulo cells (data not shown). The arrows show Wolbachiastained in red and the DNA is stained in blue using DAPI 


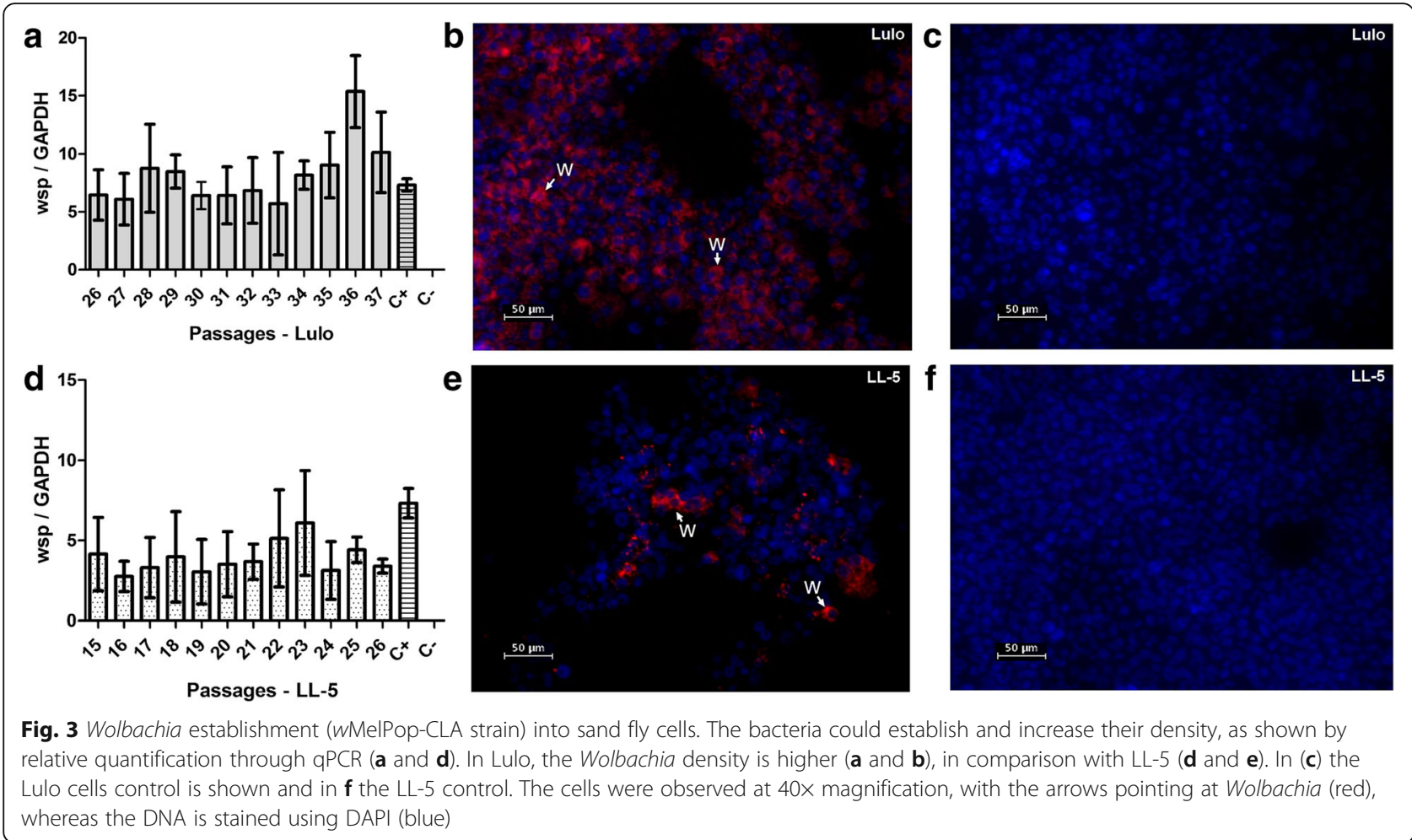

After transinfection with wMelPop, we were able to maintain and revive Lulo cells that were frozen and cryogenically stored. After revival of samples which had been frozen for over 6 months, it was possible to re-establish the culture with similar Wolbachia densities as they had prior to the freezing process, suggesting that $w$ MelPop infections in Lulo cell lines were successfully performed and can be stored for long-term use. However, after thawing aliquots stored in liquid nitrogen, it was difficult of maintain the Wolbachia density in similar levels in LL-5 cells.

\section{Wolbachia effect in immune-related gene expression in stable infections of $L$. longipalpis cells}

Once stable Wolbachia infections in sand fly cells had been obtained, we performed studies to determine whether the introduction of the bacterium could trigger cell immune responses. Once $w$ MelPop-CLA was established in both LL-5 and Lulo cell lines, aliquots from each passage were collected for RNA extraction and gene expression analyses. We selected genes from the Toll, IMD and Jak-Stat pathways, and we also evaluated the expression of other immune-related genes including AMPs. For this experiment, all the biological replicates from each cell line had similar Wolbachia densities for better comparison among groups, with the average Wolbachia density being higher in Lulo than in LL-5 cells (Fig 3a, d). The wMelPop-infected LL-5 line showed no significant difference in any of the genes studied compared to their appropriate controls $(P>0.05)$.

Surprisingly, in Lulo cells which had higher Wolbachia density than LL-5 cells, gene expression for Cactus 1 (Mann-Whitney U-test; $U=94, P=0.0073$ ), Caspar (Mann-Whitney U-test; $U=78.5, P=0.0018$ ), PIAS (Mann-Whitney U-test; $U=109.5, P=0.0396$ ), Prophenoloxidase (Mann-Whitney U-test; $U=46, P=0.0003$ ) and TEP1 (Mann-Whitney U-test; $U=58, P=0.0018$ ) was significantly lower in comparison with the uninfected Lulo counterparts (Fig. 4). For the genes studied Myd88 (Mann-Whitney U-test; $P=0.8441$ ) and Relish (Mann-Whitney U-test; $P=0.1806$ ), including the AMPs Attacin (Mann-Whitney U-test; $P=0.8604$ ), Cecropin (Mann-Whitney U-test; $P=0.5428$ ) and Defensin (Mann-Whitney U-test; $P=0.5979)$, wMelPop-infected Lulo cells showed no significant differences compared to the control Lulo cells $(P>0.05)$ (Fig. 4).

\section{Leishmania (L.) infantum interaction in Wolbachia-infected \\ L. longipalpis cells}

Experiments of Leishmania interactions into Wolbachia-infected cells were performed with high density (10:1 Wolbachia:cell) and low density (5:1 Wolbachia:cell) Wolbachia infections, in comparison to uninfected Lulo cells (controls). We tested parasite load rates of 10:1, 5:1, 1:1 and 0.1:1 parasites per cell. Forty-eight hours post-incubation with Leishmania, a large number 


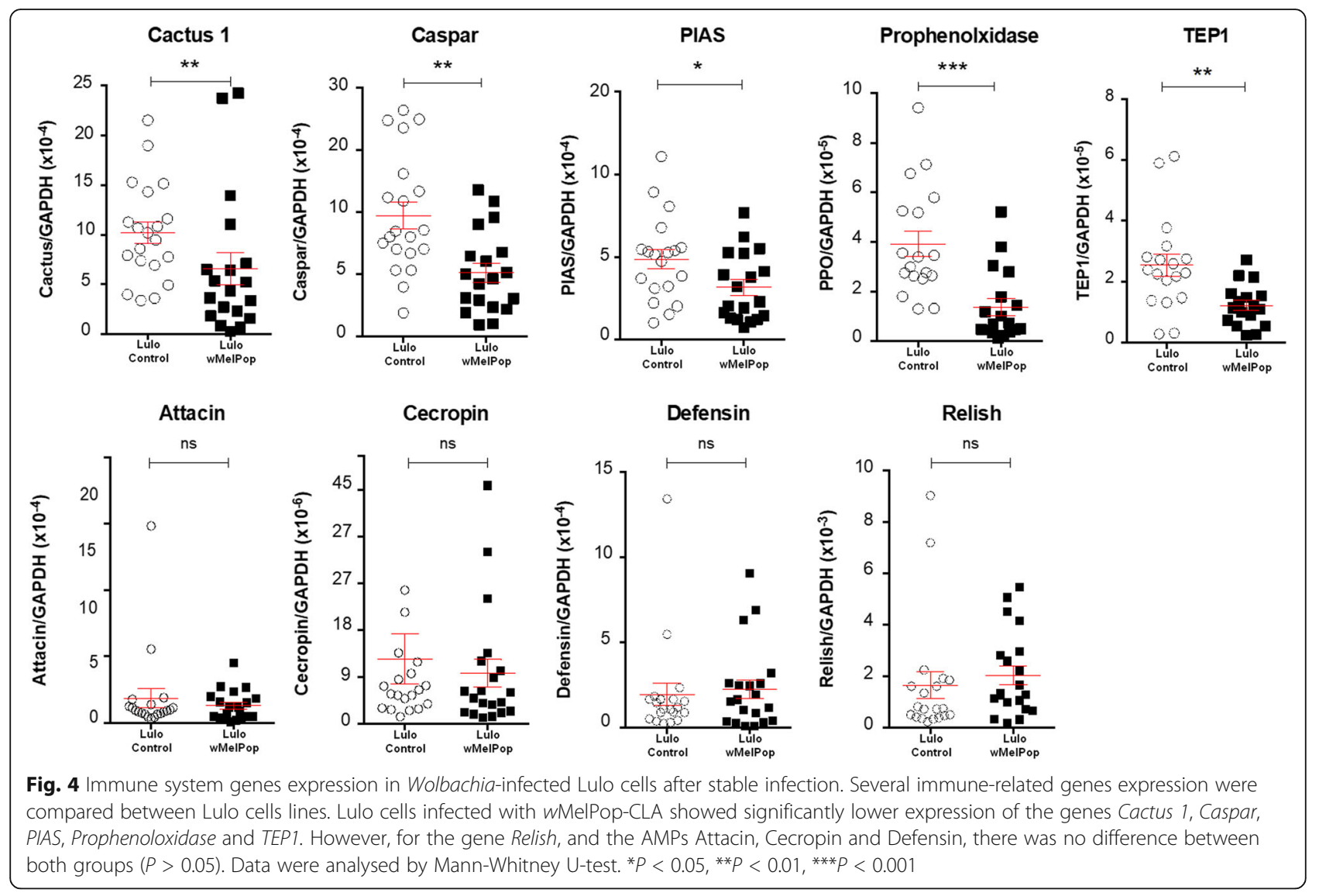

of cells detached from the glass coverslip at the higher concentrations of parasites (10:1 and 5:1), making it difficult to analyse the results. Due to the loss of cells after exposure to Leishmania, we determined that the best concentration for Leishmania interaction was the 1:1 ratio (parasite:cell). At two hours of interaction, the cells with high Wolbachia density (ratio 10:1) had fewer parasites adhered to the cells in comparison with the other two groups, although with no significant difference (two-way ANOVA; $F_{(6,27)}=1.04, P=0.4232$ ). At the same time, the groups with low Wolbachia density (ratio 5:1) and the control reached the highest percentage of cells with adhered parasite, in comparison with other time-points, but they were not statistically different (two-way ANOVA; $F_{(2,9)}=0.07, P=0.9335$ ). At 24,48 and $72 \mathrm{~h}$ post-incubation, all three groups showed a similar percentage of cells with attached $L$. infantum (two-way ANOVA; $F_{(3,27)}=2.10, P=0.1233$ ) (Fig. 5).

\section{Discussion}

Wolbachia establishment in cell lines is the first step towards this endosymbiont establishment in novel hosts. This eliminates the need to rear insects through several generations, especially because sand fly rearing is a laborious process and very few productive laboratory colonies are available worldwide. Here we show the first establishment of Wolbachia in phlebotomine cell lines. In this study, the introduction and establishment of the bacteria into sand fly cells was difficult, perhaps because the natural host, the brachyceran fly Drosophila melanogaster, is not closely related to the nematoceran L. longipalpis [43]. Furthermore, it was proposed in previous studies that not only the genetic background, but also the cytoplasmic components of the Wolbachia-free cell line are important factors for Wolbachia establishment [44].

The first trials to infect LL-5 cells with $w$ Mel or $w$ MelPop-CLA were not successful and our results indicate that early increased expression of AMPs and oxidative stress may be involved in reducing Wolbachia survival within these cells. Previous studies showed that LL-5 cells presented increased immune responses after challenges with heat-killed bacteria and yeast [40]. Together these results indicate that LL-5 cells immune response can have a significant impact on bacterial survival prior to reaching a stable infection.

Initial attempts to obtain a stable Wolbachia infection using the strain $w$ Mel in sand fly cells failed, probably 


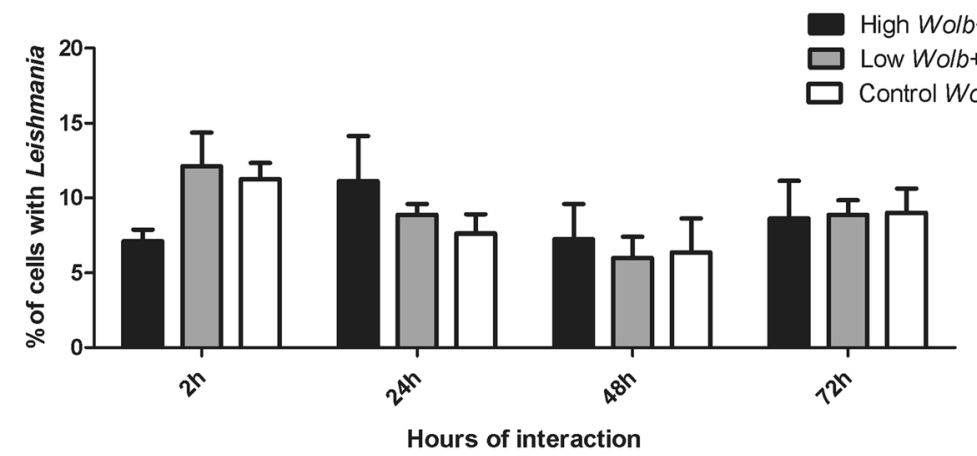

Fig. 5 Leishmania (L.) infantum interaction with Lulo cell lines. Leishmania interaction with the sand fly cells at 2, 24, 48 and 72 h of co-incubation. The Leishmania interaction was performed in three different groups. In black, Lulo cells containing high Wolbachia density (ratio 10:1 Wolbachia per cell); in grey, Lulo with containing low Wolbachia density (ratio 5:1 Wolbachia per cell); in white, control Lulo cells (uninfected with Wolbachia). Data are expressed in percentile values (\%) and represent the average and standard deviation of four independent experiments. Data were analysed by Mann-Whitney U-test and no significant differences were observed between the groups $(P>0.05)$

due to the low density of this strain in mosquito cell lines. In contrast, we could introduce and maintain the strain $w$ MelPop in Lulo and LL-5 cell lines, although the density was different in each line. The Wolbachia infection was maintained at a lower density in LL-5 cells compared to Lulo cells, suggesting Lulo cells are a better model for in vitro studies involving Wolbachia.

Once established, experiments to determine the expression of immune genes in the presence of Wolbachia were performed in both Lulo and LL-5 sand fly cells, which are important defence mechanism of insects against pathogens. Due to a small number of studies involving the immune system activation in sand flies, genes from the innate immune system pathways were selected based on the annotated genome of L. longipalpis (https://www.vectorbase.org/organisms/lutzomyia-longipalpis). The genes studied include Cactus and Caspar, which negatively control the Toll and IMD pathways in insects $[45,46]$ and the gene PIAS which negatively controls the Jak-Stat pathway [47]. Additionally, we studied the prophenoloxidase genes, involved in pathogen melanisation, and TEP1, which codes for a complement-like protein similar to the vertebrate C3b involved in pathogen opsonisation [48].

For stable infections of LL-5 cells, we found that Wolbachia had no effect on the expression levels of any of the genes tested in comparison with the uninfected cells, whereas for Lulo, which acquired higher Wolbachia density, the presence of the endosymbiont decreased the expression of some genes from the main immune system pathways, such as Cactus, Caspar, PIAS, PPO and TEP1. Caspar downregulation suggests that upon Wolbachia transinfection, this immune pathway may be activated in Lulo cells. After $w$ MelPop-CLA introduction, both genes Cactus and PIAS were downregulated in infected cells in comparison to their respective controls, also suggesting Toll and Jak-Stat activation upon Wolbachia infection. These results were the first indication that Wolbachia can affect the sand fly immune system pathways in different cascades.

It was previously shown that a reduction of Caspar gene expression contributes to the protection of L. longipalpis against Leishmania infections in vivo [49]. In mosquitoes, after knocking down the same gene, infections with Plasmodium were decreased [50]. In the present study, Wolbachia in Lulo cells significantly reduced the expression of Caspar; however, the Leishmania load in cells with and without the bacteria remains similar in in vitro infection experiments.

In vivo studies have shown a high antiparasitic activity of the antimicrobial peptide Defensin against Leishmania in its natural host Phlebotomus duboscqi [51]. Similarly, Defensin and Cecropin, other antimicrobial peptides, have the same antiparasitic activity in different hosts infected with a range of parasites [52-54]. For both Lulo and LL-5, there was no difference between the levels of AMPs expressed from Wolbachia stably infected and control cells. This same result was previously observed in Drosophila and mosquitoes, suggesting that the protection provided by Wolbachia is not only based on upregulation of immune system genes from the main pathways and AMPs [55-57].

Experiments with $L$. infantum were performed to test whether the presence of Wolbachia in sand fly cells could confer some protection and decrease the number of adhered parasites. Previous studies have shown that Lulo cells are a good model to study Leishmania interaction and the parasite life-cycle [41, 43]. As mentioned in previous studies, the nectomonad promastigotes act to establish infection in sand flies by attaching to the midgut wall and then by migrating to the anterior midgut [58, 59]. In 2003, Gossage et al. [60] showed that, in in vitro assays, it is possible to obtain the different forms of the parasite, such as procyclic, nectomonad, leptomonad and 
metacyclic promastigoes. In the present study, we were able to confirm the parasite interaction in both cells with and without the presence of Wolbachia (wMelPop-CLA). The number of Lulo cells with Leishmania remains similar in all three groups in different times post-co-interaction. Our results show that Wolbachia does not result in a detrimental effect against $L$. infantum adhesion in in vitro assays.

Wolbachia has been shown to inhibit the replication of dengue, Zika and chikungunya viruses in invertebrate hosts $[17,20,61,62]$ and this is the basis for biocontrol approaches to reduce the burden of these diseases (www.worldmosquito.org). The same has been shown for the parasites Plasmodium spp., which need to get into the cells for multiplication and continuation of the life-cycle $[19,31]$. It has been speculated that the blocking effect can be due to a number of mechanisms, such as competition between the bacteria and pathogen to invade the host cell and for cellular resources and/or the priming of host immune genes $[17,20,63]$.

In contrast, in the sand fly host, the key for a successful transmission of the parasite to the vertebrate host consists in the adhesion of promastigotes to the midgut epithelium using membrane molecules, such as lipophosphoglycan (LPG) and glycosaminoglycan (GAG) [39, 64-66]. In our results, the presence of Wolbachia in sand fly cells did not affect the number of Leishmania attached to Lulo cells. This was likely due to the lack of competition between Wolbachia and Leishmania to invade the host cells and for cellular resources, including the lack of upregulation of some immune system from the L. longipalpis cell lines.

The establishment and adaptation of Wolbachia into cell lines from $L$. longipalpis could potentially facilitate the generation of stably transinfected sand flies to be challenged with Leishmania. In vivo experiments involving Wolbachia and Leishmania are important due to the complexity of this organism and the life-cycle of the parasite. To better understand the use of Wolbachia against Leishmania infection and its possible antiparasitic effects, further experiments must be done with the sand fly invertebrate host to analyse the possibility of using Wolbachia as an additional tool to control leishmaniasis.

\section{Conclusions}

In this study, we were able to establish a stable infection of Wolbachia into L. longipalpis cells (Lulo cell line) and we showed that this model is more permissive to the wMelPop-CLA than the wMel Wolbachia strain. The presence of the bacterium appears to activate the main innate sand fly immune pathways but it does not appear to affect the parasite load of this specific strain of $L$. infantum attached to the cells, in comparison with uninfected Lulo cells.

\section{Methods \\ Cell lines maintenance}

Previously established embryonic cell lines from $L$. longipalpis, LL-5 [53] and Lulo [39] were cultured in $25 \mathrm{~cm}^{2}$ flasks containing L15 medium (Leibovitz 1963) enriched with $10 \%$ tryptose phosphate broth and supplemented with $10 \%$ heat inactivated fetal bovine serum (FBS; Gibco, Scoresby, Australia), penicillin $(100 \mathrm{U} / \mathrm{ml})$ and streptomycin $(100 \mu \mathrm{g} / \mathrm{ml})$. Cells were incubated at $28{ }^{\circ} \mathrm{C}$ without $\mathrm{CO}_{2}$. Confluent cell monolayers from both cell lines were mechanically removed using scrapers and passaged at least once per week. In between the passages, the old medium was discarded and fresh medium was added every 3-4 days to avoid the cells being kept for long periods in acidic medium.

The wMel- and wMelPop-CLA-infected RML-12, including the uninfected RML-12 cell lines from the mosquito species Aedes albopictus [66, 44] were obtained from The World Mosquito Program at Monash University (Melbourne, Australia). Both Wolbachia strains used to infect these lines were derived from Drosophila melanogaster, established in 2008 by McMeniman et al., and were cultured as previously described $[29,44]$.

\section{Wolbachia purification and introduction into L. longipalpis cell lines}

The process of infection of L. longipalpis cells with Wolbachia wMel and wMelPop-CLA was carried out using a modified Wolbachia extraction protocol [67]. Briefly, RML-12 cells infected with $w$ Mel and wMelPop-CLA were first cultured in six $175 \mathrm{~cm}^{2}$ flasks containing 20 $\mathrm{ml}$ of medium. Cells were grown up to $90 \%$ confluence and $70 \mathrm{ml}$ of medium containing cells $\left(\approx 2.5 \times 10^{8}\right.$ cells $)$ was collected and transferred to Falcon tubes for centrifugation at $1000 \times g$ for $10 \mathrm{~min}$ at $4{ }^{\circ} \mathrm{C}$. Pelleted cells were then resuspended in $10 \mathrm{ml}$ of SPG buffer $(218 \mathrm{mM}$ sucrose, $3.8 \mathrm{mM} \mathrm{KH} \mathrm{PO}_{4}, 7.2 \mathrm{mM} \mathrm{K}{ }_{2} \mathrm{HPO}_{4}, 4.9 \mathrm{mM}$ L-glutamate, $\mathrm{pH} 7.2$ ) and sonicated twice for $10 \mathrm{~s}$ at 20$25 \mathrm{~V}$ on ice. Homogenates were centrifuged at $1000 \times g$ for $10 \mathrm{~min}$ at $4{ }^{\circ} \mathrm{C}$. The supernatant was first filtered through a $2.7 \mu \mathrm{m}$ Millex syringe filter and then through a $1.2 \mu \mathrm{m}$ filter (Millipore, Bedford, MA, USA). The filtrate was centrifuged at $14,000 \times g$ for $15 \mathrm{~min}$ at $4{ }^{\circ} \mathrm{C}$ to obtain the Wolbachia pellet. The bacteria pellet was resuspended in SPG buffer and laid on a monolayer of $80 \%$ confluent, uninfected Lulo, LL-5, or RML-12 cells in a 24-well plate. The plate with cells and Wolbachia was sealed with parafilm and centrifuged for $60 \mathrm{~min}$ at $1500 \times g$ to increase the contact between the bacteria and the cells and finally incubated at $26{ }^{\circ} \mathrm{C}$. Three days 
after infection, cells were transferred into a $25 \mathrm{~cm}^{2}$ flask containing $4 \mathrm{ml}$ of fresh medium and passaged as described above. Additionally, multiple infections were tested following the same protocol of Wolbachia extraction for both L. longipalpis cell lines to boost Wolbachia infection rates. After the first infection in a 24-well plate, the cells were transferred to 12-well plate to grow until they were $90 \%$ confluent and then they were transferred back to 24-well plates for re-infection with Wolbachia. Three independent rounds of infection were performed as an attempt to obtain higher infection levels.

\section{Wolbachia purification and immune gene expression in early stage of infection into LL- 5 cell lines}

The same protocol of Wolbachia extraction was performed for the study of early stage of infections in LL-5 cells with both strains. One day before the Wolbachia extraction from RML- 12 cells, $200 \mu$ of LL-5 cells $(\approx 2$ $\times 10^{6}$ cells) were seeded in a 24-well plate containing 800 $\mu \mathrm{l}$ of fresh medium. After performing the same protocol described above, $100 \mu \mathrm{l}$ of the extracted Wolbachia ( $w$ Mel and $w$ MelPop-CLA) were added to each well and, for control, the same volume of SPG buffer was added, the plate sealed and centrifuged for $60 \mathrm{~min}$ at $1500 \times \mathrm{g}$ to increase the contact between the bacteria and the cells, and finally incubated at $26{ }^{\circ} \mathrm{C}$. After infection, the cells were monitored for $6,12,24,48$ and $72 \mathrm{~h}$. At each time-point, the cells attached to the 24-well plate were resuspended, centrifuged at $4000 \times g$ for $5 \mathrm{~min}$, the pellet resuspended in $50 \mu \mathrm{l}$ of TRIzol reagent (Invitrogen, Carlsbad, USA) and all samples were kept at $-80{ }^{\circ} \mathrm{C}$ until further experiments. Those samples were thawed at room temperature and homogenized using a $2 \mathrm{~mm}$ glass bead on a Mini-Beadbeater-96 (Biospec, Bartlesville, USA) for $30 \mathrm{~s}$. Total RNA was isolated following the manufacturer's instructions. For cDNA synthesis, $1 \mu \mathrm{g}$ of RNA was first treated with DNAse I (Invitrogen) and the first strand cDNA synthesis was performed by Superscript Reverse Transcriptase III (Invitrogen), both following the manufacturer's protocol. This assay was performed in three independent experiments. Wolbachia relative quantification was performed by $\mathrm{qPCR}$ using wsp [68] gene expression relative to L. longipalpis GAPDH reference gene (ID: LLOJ001891) with primers listed in Table 1. Expression of immune related genes was also performed by qPCR relative to GAPDH gene. Primers used for immunity gene expression such as Cactus and Dorsal (Toll pathway); Caspar and Relish (IMD pathway); PIAS and STAT (Jak-Stat pathway); Attacin, Cecropin, Defensin 2 [69] and Defensin 1 [69] (AMPs); and reactive oxygen species mediated immunity genes Catalase (ID: LLOJ007605), Superoxide Dismutase (SOD3A) (ID: LLOJ008594) and inducible Nitric Oxide
Table 1 Primers used in LL-5 cells early infections with wMel and wMelPop-CLA strains

\begin{tabular}{lll}
\hline Primer name & Primer sequence (5'-3') & $\begin{array}{l}\text { Reference } \\
\text { sequence ID }\end{array}$ \\
\hline LLiNOS-F & TGGCTGTCGCAATTTGTGG & $\begin{array}{l}\text { LLOJ005465 } \\
\text { (VectorBase) }\end{array}$ \\
LLiNOS-R & CCGCAATGTTCACCTCAACC & LLOJ007605 \\
LLCatalase-F & CGACCGTGGTATCCCTGATG & (VectorBase) \\
LLCatalase-R & AGAAGGCCTCCCCTTTTTG & LLOJ008594 \\
LLSOD3A-F & CCGATAGCGCTGTGAGACAC & (VectorBase) \\
LLSOD3A-R & ATCGGAAATGCGACCTTGC & LLOJ001891 \\
GAPDH-F & TTCGCAGAAGACAGTGATGG & (VectorBase) \\
GAPDH-R & CCCTTCATCGGTCTGGACTA & \\
wsp-F & TGGTCCAATAAGTGATGAAGAAAC & AF020070.1 \\
wsp-R & AAAAATTAAACGCTACTCCA & (GenBank) \\
\hline
\end{tabular}

Synthase (iNOS) (ID: LLOJ005465) were obtained from referred publications or listed in Table 1 . The reactions were performed on a 7500 Real Time PCR System (Applied Biosystems, Foster City, USA) using Power SYBR Green PCR Master Mix (Applied Biosystems) according to the manufacturer's standard protocol. Each sample, in duplicate, was analysed through the 2- $\Delta \Delta \mathrm{Ct}$ method. The relative gene expression was expressed as fold change calculated relative to uninfected LL- 5 control group. Two-way ANOVA test was used to verify significant differences of relative gene expression in relation to Wolbachia infection and time post-infection.

\section{Wolbachia detection and quantification through PCR amplification in stable infections}

On every passage, $200 \mu \mathrm{l}$ of cells and media were harvested from the flasks to confirm and estimate Wolbachia infection rates. Briefly, the cells were centrifuged at $4000 \times g$ for $5 \mathrm{~min}$, and the pellet resuspended in $50 \mu \mathrm{l}$ of extraction buffer containing $4 \mathrm{mM}$ EDTA, $20 \mathrm{mM}$ Tris base, $0.4 \mathrm{mM} \mathrm{NaCl}$ and $0.25 \mu \mathrm{g} / \mathrm{ml}$ Proteinase $\mathrm{K}$ (Bioline, Eveleigh, Australia). The cells were homogenised using a $2 \mathrm{~mm}$ glass bead and Mini-Beadbeater-96 (Biospec) for $30 \mathrm{~s}$, and the lysate then incubated at $56{ }^{\circ} \mathrm{C}$ for $5 \mathrm{~min}$, followed by a second incubation at $98{ }^{\circ} \mathrm{C}$ for 5 min for DNA extraction. Relative quantitative PCR was performed using the primers wspTM_F (5'-CAT TGG TGT TGG TGT TGG TG-3') and wspTM_R (5'-ACA CCA GCT TTT ACT TGA CCA G-3') [70] for Wolbachia and GAPDH_F (5'-TTC GCA GAA GAC AGT GAT GG-3') and GAPDH_R (5'-CCC TTC ATC GGT CTG GAC TA-3') for L. longipalpis. The reactions were performed on a LightCycler 480 SYBR Green I Master (Roche, North Ryde, Australia) at $95{ }^{\circ} \mathrm{C}$ for 5 min, followed by 45 cycles at $95{ }^{\circ} \mathrm{C}$ for $30 \mathrm{~s}, 60^{\circ} \mathrm{C}$ for 30 s and $72{ }^{\circ} \mathrm{C}$ for $2 \mathrm{~s}$, with an extra $72{ }^{\circ} \mathrm{C}$ for $5 \mathrm{~min}$. Each 
sample, in duplicate, was analysed through the $2-\Delta \Delta \mathrm{Ct}$ method by the LightCycler 480 software (Roche).

\section{Wolbachia visualisation by fluorescence in situ hybridization (FISH)}

Every 3rd or 4th passage after Wolbachia infection, 100 $\mu \mathrm{l}$ of the sand fly cells at $90 \%$ confluence was transferred to an 8-well chamber slide (Thermo Fisher, Riverstone, Australia) containing $400 \mu \mathrm{l}$ of media and incubated at $26{ }^{\circ} \mathrm{C}$ for at least $3 \mathrm{~h}$, to allow cell adhesion prior to the FISH assay. After incubation, cells were processed by FISH as previously described [44]. Briefly, cells were fixed for $10 \mathrm{~min}$ in freshly prepared $4 \%$ formaldehyde in $1 \times$ PBS buffer with $0.5 \%$ Triton X-100, washed 3 times in $1 \times$ PBS for $5 \mathrm{~min}$ each and incubated in absolute ethanol for 5 min. This was followed by the hybridization process conducted overnight at $37{ }^{\circ} \mathrm{C}$ with a hybridization buffer [ $50 \%$ formamide, $5 \times$ saline-sodium citrate (SSC), $200 \mathrm{~g} / \mathrm{l} \mathrm{dex-}$ tran sulfate, $250 \mathrm{mg} / \mathrm{l}$ poly(A), $250 \mathrm{mg} / \mathrm{l}$ salmon sperm DNA, $250 \mathrm{mg} / \mathrm{l}$ tRNA, $0.1 \mathrm{M}$ of DTT (1,4-dithiothreitol), $0.5 \times$ Denhartdt's solution] containing $200 \mathrm{ng}$ of each of the specific Wolbachia probes for $16 S$ rRNA (W2: 5'-CTT CTG TGA GTA CCG TCA TTA TC-3' and W3: 5'-AAC CGA CCC TAT CCC TTC GAA TA-3'), labelled by Rhodamine at the $5^{\prime}$ end [71]. After hybridization, samples were washed twice in $10 \mathrm{mM}$ DTT in $1 \times$ SSC and then twice in $10 \mathrm{mM}$ DTT in $0.5 \times \mathrm{SSC}$ at $55^{\circ} \mathrm{C}$ and for $15 \mathrm{~min}$ each, followed by a wash with $10 \mathrm{mM}$ DTT in $0.5 \times \mathrm{SSC}$, at room temperature. To observe DNA, cells were washed in $10 \mathrm{mM}$ DTT in $0.5 \times \mathrm{SSC}$ supplemented with $10 \mathrm{mg} / \mathrm{ml}$ DAPI (4,6- diamidino-2-phenylindole, dihydrochloride) for $10 \mathrm{~min}$ at room temperature, rinsed three times in Mili-Q water, and mounted on a glass slide with Prolong Gold (Life Technologies, Scoresby, Australia). Samples were viewed under an epifluorescence microscope (AXIO Imager II, Zeiss, Le Pecq, France) equipped with Axiocam, using $20 \times$ and $40 \times$ objectives.

\section{Immune gene expression in stable infections in sand fly cells}

From passage 18th onwards (approximately 18 weeks after infection), in each passage $200 \mu \mathrm{l}$ of cells and media at $90 \%$ confluence were harvested $\left(\approx 4 \times 10^{6}\right.$ cells $)$, centrifuged at $4000 \times g$ for $5 \mathrm{~min}$, the pellet resuspended in TRIzol reagent (Invitrogen) and all samples kept at $-80{ }^{\circ} \mathrm{C}$ until further experiments. Samples with similar Wolbachia density were selected for immune system gene expression experiments. Those samples were thawed at room temperature and homogenized using a $2 \mathrm{~mm}$ glass bead on a Mini-Beadbeater-96 (Biospec) for $30 \mathrm{~s}$. Total RNA was isolated following the manufacturer's instructions. For cDNA synthesis, $2 \mu \mathrm{g}$ of RNA was first treated with DNAse I (Invitrogen) and the first strand cDNA synthesis was performed by the Superscript Reverse Transcriptase
III (Invitrogen), both following the manufacturer's protocol. For immune system expression, primers for genes from different immune pathways were designed using the Primer-BLAST tool (NCBI, https://www.ncbi.nlm.nih.gov/ tools/primer-blast/). The sequences were based on the $L$. longipalpis annotated genome available at VectorBase. Gene IDs used for primer design are as follows: Cactus1 (ID: LLOJ004612), Caspar (ID: LLOJ002950), PIAS (ID: LLOJ002593-RA), Prophenoloxidase (ID: LLOJ001742) and TEP1 (ID: LLOJ007923). Furthermore, primers designed for the genes Relish, the antimicrobial peptide genes (AMPs) Attacin, Cecropin and Defensin previously described [40] were also included in this study. The same conditions for quantitative PCR were applied, as previously described in this study for Wolbachia density, and each sample was performed in duplicate. Expression analysis was performed through the relative quantification using qGENE and normalized to GAPDH. Statistical significance between all data sets was determined using the Mann-Whitney U-test (Graph Pad Prism, version 5.03).

\section{Leishmania interaction with Lulo cells}

To test the effect of Wolbachia on Leishmania adhesion, we used Lulo cells with and without Wolbachia, and promastigotes of L. infantum (MHOM/BR/1974/PP75). We tested two different densities of Wolbachia-infected cells to investigate whether the amount of bacteria in those cells could interfere with the parasite adhesion and interaction with the sand fly cell lines. The parasites were grown in Schneider's media (Gibco) supplemented with $10 \% \mathrm{v} / \mathrm{v}$ heat-inactivated FBS (Gibco), 1\% v/v GlutaMAX (Gibco), 1\% v/v BME Vitamins solution 100× (Sigma-Aldrich, Castle Hill, Australia), $2 \%$ sterile male urine and penicillin $(100 \mathrm{U} / \mathrm{ml})$ and streptomycin $(100 \mu \mathrm{g} / \mathrm{ml})$ (Gibco), maintained at $28{ }^{\circ} \mathrm{C}$ without $\mathrm{CO}_{2}$. The assay was performed as previously described with some modifications $[43,44]$. Briefly, Lulo cells infected and uninfected with Wolbachia were seeded on glass coverslips in a 24-well plate, to a final number of $2 \times 10^{6}$ cells per well, one day before the interaction with parasites. For the cell/ promastigote interaction assay, different concentrations of $L$. infantum and cells were tested (10:1, 5:1, 1:1 and 0.1:1) for standardisation and a ratio of about 1:1 parasite/cell was used. After $2 \mathrm{~h}$ of co-incubation and interaction, the non-adhered promastigotes were washed off with phosphate buffered saline (PBS) pH 7.2 and the cells were monitored for 2, 24, 48 and $72 \mathrm{~h}$. At each time-point, the cells attached to the coverslip were fixed with methanol and stained with Quick Dip Field Staining (Thermo Fisher, Riverstone, Australia) and mounted with Canada Balsam (Sigma-Aldrich) in slides for further analysis. Three independent experiments were performed.

After conducting all the time-point collections, the number of promastigotes attached per cell in both Wolbachia-infected and uninfected lines was determined by 
counting 200 cells per coverslip under a light microscope (AXIO Imager II, Zeiss) equipped with Axiocam, using $100 \times$ objectives. This assay was performed in four independent experiments and the results were expressed as the percentage of cells with the parasite at different times post-exposure to the parasite. The statistical analysis was performed using two-way ANOVA test to verify significant differences of the L. infantum adhesion in relation to Wolbachia infection and time post-infection, and also Bonferroni post-hoc tests, both using GraphPRISM software (version 5.03).

\section{Additional file}

Additional file 1: Table S1. Statistical analysis of $L L-5$ sand fly cells immune response after early Wolbachia infections (WMel or WMelPop-CLA strains). (DOCX $20 \mathrm{~kb}$ )

\section{Abbreviations}

AMPs: Antimicrobial peptides; cDNA: Complementary deoxyribonucleic acid; CHIKV: Chikungunya virus; DENV: Dengue virus; DNA: Deoxyribonucleic acid; FISH: Fluorescence in situ hybridization; GAG: Glycosaminoglycan; LPG: Lipophosphoglycan; PBS: Phosphate-buffered saline; qPCR: Quantitative polymerase chain reaction; RNA: Ribonucleic acid; rRNA: Ribosomal ribonucleic acid; VL: Visceral leishmaniasis

\section{Acknowledgements}

We wish to thank Adalberto Santos Dias for providing the parasites for the experiments and Saijo Thomas for all helpful science discussions. We also thank Heather Flores and David Claude Hack for critical reading. Finally, we want to thank Dr Scott O'Neill who provided all the infrastructure in his laboratory for this study.

\section{Funding}

DSG, MRVS and LAM were funded by CNPq and CAPES grants. Also, the Brazilian Ministry of Health and a grant to Monash University from the Bill and Melinda Gates Foundation. YMTC was funded by the Instituto Oswaldo Cruz, Fiocruz, Brazil.

\section{Availability of data and materials}

All data generated or analysed during this study are included in this published article.

\section{Authors' contributions}

DSG participated in the design of the study, carried out most experiments and drafted the manuscript. LAM, MRVS and YMTC participated in the study design and reviewing the manuscript. MNR helped with the Leishmania interaction experiments. LAM and MRVS coordinated the work, critically reviewed the manuscript and contributed to achieving the results. $\| O$, AMS and ELT participated in the experiment design and execution, and SLO provided critical comments to the protocol and experiments. All authors read and approved the final manuscript.

\section{Ethics approval and consent to participate}

Not applicable.

\section{Consent for publication}

Not applicable.

\section{Competing interests}

The authors declare that they have no competing interests.

\section{Publisher's Note}

Springer Nature remains neutral with regard to jurisdictional claims in published maps and institutional affiliations.

\section{Author details}

'Grupo Mosquitos Vetores: Endossimbiontes e Interação Patógeno Vetor, Centro de Pesquisas René Rachou - Fundação Oswaldo Cruz, Av. Augusto de Lima 1715, 30190-002. Belo Horizonte, Belo Horizonte, MG, Brazil. World Mosquito Program, Institute of Vector-Borne Disease, Monash University, 12 Innovation Walk, Clayton, VIC 3800, Australia. ${ }^{3}$ Laboratório de Biologia Molecular de Parasitos e Vetores, Instituto Oswaldo Cruz - Fundação Oswaldo Cruz, Av. Brasil, 4365, Rio de Janeiro, RJ 21040-900, Brazil. ${ }^{4}$ Laboratório de Insetos Hematófagos, Departamento de Parasitologia, Instituto de Ciências Biológicas/UFMG, Av. Antônio Carlos, 6627, 31270-901. Belo Horizonte, Belo Horizonte, MG, Brazil.

Received: 10 May 2018 Accepted: 21 November 2018

Published online: 15 January 2019

References

1. Alvar J, Vélez ID, Bern D, Herrero M, Desjeux P, Can J, et al. Leishmaniasis worldwide and global estimates of its incidence. PLoS One. 2012;7:e35671.

2. WHO. Leishmaniasis. 2016. http://www.who.int/leishmaniasis/en/. Accessed 25 Sept 2017.

3. McCall LI, Zhang WW, Matlashewski G. Determinants for the development of visceral leishmaniasis disease. PLoS Pathog. 2013;9:e1003053.

4. Desjeux P. Leishmaniasis: public health aspects and control. Clin Dermatol. 1996;14:417-23.

5. Pigott DM, Bhatt S, Golding N, et al. Global distribution maps of the leishmaniasis. eLife. 2014:3:e02851.

6. Gavgani ASM, Hodjati MH, Mohite H, Davies CR. Effect of insecticideimpregnated dog collars on incidence of zoonotic vissceral leishmaniasis in Iranian children: a matched-cluster randomised trial. Lancet. 2002;360:374-9.

7. Bern C, Joshi AB, Jha SN, Das ML, Hightower A, Thakur GD, Bista MB. Factors associated with visceral leishmaniasis in Nepal: bed-net use is strongly protective. Am J Trop Med Hyg. 2003;63:184-8.

8. DPDx - Center for Diease Control and Prevention Leishmaniasis. 2017. http://www.cdc.gov/dpdx/leishmaniasis/index.html. Accessed 30 Sept 2017.

9. Hilgenboecker K, Hammerstein P, Schlattmann P, Telschow A, Werren JH. How many species are infected with Wolbachia? - a statistical analysis of current data. FEMS Microbiol Lett. 2008;281:215-20.

10. Zug R, Hammerstein P. Still a host of hosts for Wolbachia: analysis of recent data suggests that $40 \%$ of terrestrial arthropod species are infected. PLoS One. 2012;7:e38544

11. De Oliveira CD, Goncalves DS, Baton LA, Shimabukuro PHF, Carvalho FD, Moreira LA. Broader prevalence of Wolbachia in insects including potential human disease vectors. Bull Entomol Res. 2015;105:305-15.

12. Teixeira L, Ferreira A, Ashburner M. The bacterial symbiont Wolbachia induces resistance to RNA viral infections in Drosophila melanogaster. PLoS Biol. 2008:23:e2

13. Hedges LM, Brownlie JC, O'Neill SL, Johnnson KN. Wolbachia and virus protection in insects. Science. 2002;322:702.

14. Xi Z, Gavotte L, Xie Y, Dobson SL. Genome-wide analysis of the interaction between the endosymbiotic bacterium Wolbachia and its Drosophila host. BMC Genomics. 2008;9:1

15. Pan X, Pike A, Joshi D, Bian G, McFadden MJ, et al. The bacterium Wolbachia exploits host innate immunity to establish a symbiotic relationship with the dengue vector mosquito Aedes aegypti. ISME J. 2018;12:277-88.

16. Bian G, Xu Y, Lu P, Xie Y, Xi Z. The endosymbiotic bacterium Wolbachia induces resistance to dengue virus in Aedes aegypti. PLoS Pathog. 2010;6: e1000833.

17. Moreira LA, Iturbe-Ormaetxe I, Jeffery JA, Lu G, Pyke AT, Hedges LM, et al. A Wolbachia symbiont in Aedes aegypti limits infection with dengue, chikungunya, and Plasmodium. Cell. 2009;139:1268-78.

18. Hoffmann AA, Montgomery BL, Popovici J, Iturbe-Ormaetxe I, Johnson PH, Muzzi F, et al. Successful establishment of Wolbachia in Aedes populations to suppress dengue transmission. Nature. 2011;476:454-7.

19. Bian G, Joshi D, Dong Y, Lu P, Zhou G, Pan X, et al. Wolbachia invades Anopheles stephensi populations and induces refractoriness to Plasmodium infection. Science. 2013;340:748-51.

20. Dutra HLC, Rocha MN, Dias FBS, Mansur SB, Caragata EP, Moreira LA. Wolbachia blocks currently circulating Zika virus isolates in Brazilian Aedes aegypti mosquitoes. Cell Host Microbe. 2016;19:771-4.

21. Iturbe-Ormaetxe I, Walker T, O'Neill SL. Wolbachia and the biological control of mosquito-borne disease. EMBO Rep. 2011;12:508-18. 
22. Kambris Z, Blagborough AM, Pinto SB, Blagrove MSC, Godfray HC, Sinden RE, Sinkins SP. Wolbachia stimulates immune gene expression and inhibits Plasmodium development in Anopheles gambiae. PLoS Pathog. 2010;6: e1001143.

23. Ono M, Braig HR, Munstermann LE, Ferro C, O'Neill SL. Wolbachia infections of phlebotomine sand flies (Diptera: Psychodidae). J Med Entomol. 2001;38: 237-41

24. Parvizi P, Fardid F, Soleimani S. Detection of a new strain of Wolbachia pipientis in Phlebotomus perfiliewi transcaucasicus, a potential vector of visceral leishmaniasis in North West of Iran, by targeting the major surface protein gene. J Arthropod Borne Dis. 2013;7:46-55.

25. Ready PD. Biology of phlebotomine sand flies as vectors of disease agents. Annu Rev Entomol. 2013;58:227-50

26. Sant'Anna MR, Darby AC, Brazil RP, Montoya-Lerma J, Dillon VM, Bates PA, Dillon RJ. Investigation of the bacterial communities associated with females of Lutzomyia sand fly species from South America. PLoS One. 2012; 7:e42531.

27. Da Rocha NO, Lambert SM, Dias-Lima AG, Julião FS, Souza BMPS. Molecular detection of Wolbachia pipientis in natural populations of sandfly vectors of Leishmania infantum in endemic areas: first detection in Lutzomyia longipalpis. Med Vet Entomol. 2017;32:111-4

28. Walker T, Moreira LA. Can Wolbachia be used to control malaria? Mem Inst Oswaldo Cruz. 2011;106:212-7.

29. McMeniman CJ, Lane AM, Fong AWC, Voronin DA, Iturbe-Ormaetxe I, Yamada R, et al. Host adaptation of a Wolbachia strain after long-term serial passage in mosquito cell lines. Appl Environ Microbiol. 2008;74:6963-9.

30. McMeniman CJ, Lane RV, Cass BN, Fong AW, Sidhu M, Wang YF, O'Neill SL. Stable introduction of a life-shortening Wolbachia infection into the mosquito Aedes aegypti. Science. 2009;323:141-4.

31. Kambris Z, Blagborough AM, Pinto SB, Blagrove MS, Godfray HC, Sinder RE, Sinkins SP. Wolbachia stimulates immune gene expression and inhibits Plasmodium development in Anopheles gambiae. PLoS Pathog. 2010;6: e1001143.

32. Zug R, Hammerstein P. Wolbachia and the insect immune system: what reactive oxygen species can tell us about the mechanisms of Wolbachiahost interactions. Front Microbiol. 2015;6:1201.

33. Gomes B, Purkait B, Deb RM, Rama A, Singh RP, Foster GM, et al. Knockdown resistance mutations predict DDT resistance and pyrethroid tolerance in the visceral leishmaniasis vector Phlebotomus argentipes. PLoS Negl Trop Dis. 2017;11:e0005504

34. Salomón OD, Feliciangeli MD, Quintana MG, Afonso MMS, Rangel EF. Lutzomyia longipalpis urbanisation and control. Mem Inst Oswaldo Cruz. 2015;110:831-46.

35. Warburg A, Faiman R. Research priorities for the control of phlebotomine sand flies. J Vector Ecol. 2011;36:S10-6.

36. Tesh R, Modi G. Development of a continuous cell line from the sand-fly Lutzomyia longipalpis (Diptera: Psychodidae), and its susceptibility to infection with arboviruses. J Med Entomol. 1983;20:199-202.

37. Rey GJ, Ferro C, Bello FJ. Establishment and characterization of a new continuous cell line from Lutzomyia longipalpis (Diptera: Psychodidae) and its susceptibility to infections with arboviruses and Leishmania chagasi. Mem Inst Oswaldo Cruz. 2000;95:103-10.

38. Soares RP, Altoé EC, Ennes-Vidal V, da Costa SM, Rangel EF, Souza N, et al. In vitro inhibition of Leishmania attachment to sand fly midguts and LL-5 cells by divalent metal chelators, anti-gp63 and phosphoglycans. Protist. 2017; 168:326-34.

39. Côrtes LMC, Pereira MCS, Silva FS, Pereira BAS, Junior FOO, Soares ROA, et al. Participation of heparin binding proteins from the surface of Leishmania (Viannia) braziliensis promastigotes in the adhesion of parasites of Lutzomyia longipalpis cells (Lulo) in vitro. Parasit Vectors. 2012;5:142.

40. Tinoco-Nunes B, Telleria EL, da Silva-Neves M, Marques C, Azevedo-Brito DA, Pitaluga AN, Traub-Csekö YM. The sand fly Lutzomyia longipalpis LL5 embryonic cell line has active Toll and Imd pathways and shows immune responses to bacteria, yeast and Leishmania. Parasit Vectors. 2016;9:222.

41. Bello FJ, Mejía AJ, Corena MDP, Ayala M, Sarmiento L, Zuñiga C, Palau MT. Experimental infectio of Leishmania (L.) chagasi in a cell line derived from Lutzomyia longipalpis (Diptera:Psychodidae). Mem Inst Oswaldo Cruz. 2005; 100:519-25.

42. Côrtes LM, Silva RM, Pereira BA, Guerra C, Zapata AC, Bello FJ, et al. Lulo cel line derived from Lutzomyia longipalpis (Diptera: Psychodidae): a novel model to assay Leishmania spp. and vector interaction. Parasit Vectors. 2011;4:216.

43. Rafiqi AM, Park CH, Kwan CW, Lemke S, Schmidt-Ott U. BMP-dependent serosa and amnion specification in the scuttle fly Megaselia abdita. Development. 2012;139:3373-82.

44. Voronin D, Tran-Van V, Potier P, Mavingui P. Transinfection and growth discrepancy of Drosophila Wolbachia strain wMel in cell lines of the mosquito Aedes albopictus. J Appl Microbiol. 2010;108:2133-41.

45. Kim M, Lee JH, Lee SY, Kim E, Cuhng J. Caspar, a suppressor of antibacterial immunity in Drosophila. Proc Natl Acad Sci USA. 2006;103:16358-63.

46. Kingsolver MB, Huang Z, Hardy RW. Insect antivirial innate immunity: pathways, effectors, and connections. J Mol Biol. 2013;425:4921-36.

47. Kiu H, Nicholson SE. Biology and significance of the Jak/Stat signalling pathways. Growth Factors. 2012;30:88-106.

48. Povelones M, Waterhouse RM, Kafatos FC, Christophides GK. Leucine-rich repeat protein complex activates mosquito complement in defense against Plasmodium parasites. Science. 2009;324:258-61.

49. Telleria EL, Sant'Anna MRV, Ortigão-Farias JR, Pitaluga AN, Dillon VM, et al. Caspar-like gene depletion reduces Leishmania infection in sand fly host Lutzomyia longipalpis. J Biol Chem. 2012;287:12985-93.

50. Garver LS, Dong Y, Dimopoulos G. Caspar controls resistance to Plasmodium falciparum in diverse anopheline species. PLoS Pathog. 2009;5:e1000335.

51. Boulanger N, Lowenberger C, Volf P, Ursic R, Sigutova L, Sabatier L, et al. Characterization of a defensin from the sand fly Phlebotomus dubosca induced by challenge with bacteria or the protozoan parasite Leishmania major. Infect Immun. 2004;72:7140-6.

52. Akuffo $\mathrm{H}$, Hultmark D, Engstöm A, Frohlich D, Kimbrell D. Drosophila antibacterial protein, Cecropin A, differentially affects non-bacterial organisms such as Leishmania in a manner different from other amphipathic peptides. Int J Mol Med. 1998;1:77-82.

53. Durvasula RV, Gumbs A, Panackal A, Kruglov O, Aksoy S, Merrifield RB, et al. Prevention of insect-borne disease: an approach using transgenic symbiotic bacteria. Proc Natl Acad Sci USA. 1997;94:3274-8.

54. Hao Z, Kasumba I, Lehane MJ, Gibson WC, Kwon J, Aksoy S. Tsetse immune responses and trypanosome transmission: implications for the development of tsetse-based strategies to reduce trypanosomiasis. Proc Natl Acad Sci USA. 2001;98:12648-53.

55. Bourtzis K, Pettigrew MM, O'Neill SL. Wolbachia neither induces nor suppresses transcripts encoding antimicrobial peptides. Insect Mol Biol. 2000;9:635-9.

56. Wong ZS, Hedges LM, Brownlie JC, Johnson KN. Wolbachia-mediated antibacterial protection and immune gene regulation in Drosophila. PLoS One. 2011;9:e25430.

57. Rancès E, Johnso TK, Popovic J, Iturbe-Ormaetxe I, Zakir T, Warr CG, O'Neil SL. The Toll and Imd pathways are not required for Wolbachia-mediated dengue virus intereference. J Virol. 2013;87:11945-9.

58. Sacks DL, Kamhawi S. Molecular aspects of parasite-vector and vector-host interactions in leishmaniasis. Annu Rev Microbiol. 2001;55:453-83.

59. Rogers ME, Chance ML, Bates PA. The role of promastigote secretory gel in the origin and transmission of the infective stage of Leishmania mexicana by the sand fly Lutzomyia longipalpis. Parasitology. 2002;124:495-507.

60. Gossage SM, Rogers ME, Bates PA. Two separate growth phases during the development of Leishmania in sand flies: implications for understanding the life cycle. Int J Parasitol. 2003;33:1027-34.

61. Tan CH, Wong PJ, LI MI, Yang H, Ng LC, O'Neill SL. WMel limits Zika and chikungunyia virus infection in a Singapore Wolbachia-introgressed Ae. aegypti strain, wMel-Sg. PLoS Negl Trop Dis. 2017;11:e0005496.

62. Aliota MT, Walker EC, Yepes AU, Velez ID, Christensen M, Osorio JE. The WMel strain of Wolbachia reduces transmission of chikungunyia virus in Aedes aegypti. PLoS Negl Trop Dis. 2016;10:e0004677.

63. Joubert DA, Walker T, Carringtion LB, et al. Establishment of a Wolbachia superinfection in Aedes aegypti mosquitoes as a potentia approach for future resistance management. PLoS Pathog. 2016;12: e1005434.

64. Bates PA. Transmission of Leishmania metacyclic promastigotes by phlebotomine sand flies. Int J Parasitol. 2007:37:1097-106.

65. Dostálová A, Volf P. Leishmania development in sand flies: parasite-vector interactions overview. Parasit Vectors. 2012:5:276.

66. Frentiu FD, Robinsion J, Young PR, McGraw EA, O'Neill SL. Wolbachiamediated resistance to Dengue virus infection and death at the cellular level. PLoS One. 2010;15:e13398. 
67. Iturbe-Ormaetxe I, Woolfit M, Rancès E, Duplouy A, O'Neill SL. A simple protocol to obtain highly pure Wolbachia endosymbiont DNA for genome sequencing. J Microbiol Methods. 2011;84:134-6.

68. Braig HR, Zhou W, Dobson SL, O'Neill SL. Cloning and characterization of a gene encoding the major surface protein of the bacterial endosymbiont Wolbachia pipientis. J Bacteriol. 1998;180:2373-8.

69. Telleria EL, Sant'Anna MR, Alkurbi MO, Pitaluga AN, Dillon RJ, Traub-Csekö YM. Bacterial feeding, Leishmania infection and distinct infection routes induce differential defensin expression in Lutzomyia longipalpis. Parasit Vectors. 2013;6:12.

70. Frentiu FD, Tasnim Z, Walker T, et al. Limited dengue virus replication in field-collected Aedes aegypti mosquitoes infected with Wolbachia. PLoS Negl Trop Dis. 2014;8:e2688.

71. Xi Z, Khoo CC, Dobson SL. Wolbachia establishment and invasion in an Aedes aegypti laboratory population. Science. 2005;310:326-8.

Ready to submit your research? Choose BMC and benefit from:

- fast, convenient online submission

- thorough peer review by experienced researchers in your field

- rapid publication on acceptance

- support for research data, including large and complex data types

- gold Open Access which fosters wider collaboration and increased citations

- maximum visibility for your research: over $100 \mathrm{M}$ website views per year

At $\mathrm{BMC}$, research is always in progress.

Learn more biomedcentral.com/submissions 